Article

\title{
Application of Benchmarking and Principal Component Analysis in Measuring Performance of Public Irrigation Schemes in Kenya
}

\author{
Faith M. Muema ${ }^{1, *}$, Patrick G. Home ${ }^{2}$ and James M. Raude ${ }^{2}$ DD \\ 1 Civil Engineering Department, Pan African University Institute for Basic Sciences, Technology and \\ Innovation (PAUSTI), P.O. Box 62000-00200 Nairobi, Kenya \\ 2 Soil, Water and Environmental Engineering Department, Jomo Kenyatta University of Agriculture and \\ Technology (JKUAT), P.O. Box 62000-00200 Nairobi, Kenya; pghome@jkuat.ac.ke (P.G.H.); \\ ramesso@jkuat.ac.ke (J.M.R.) \\ * Correspondence: faith.mawia@yahoo.com; Tel.: +254-713-009-267
}

Received: 29 August 2018; Accepted: 4 October 2018; Published: 12 October 2018

\begin{abstract}
The inefficient water use, and variable and low productivity in Kenyan public irrigation schemes is a major concern. It is, therefore, necessary to periodically monitor and evaluate the performance of public irrigation schemes. This prompted evaluation of performance of three rice growing irrigation schemes in western Kenya using benchmarking and principal component analysis. The aim of the study was to quantify and rank the performance of selected irrigation schemes. The performance of the irrigation schemes was evaluated for the period from 2012 to 2016 using eleven performance indicators under agricultural productivity, water supply and financial performance categories. The performance indicators were weighted using principal component analysis and combined to form a single performance score using linear aggregation method. The average performance in the Ahero, West Kano and Bunyala irrigation schemes was 48\%, 49\% and 56\%, respectively. Based on performance score, the Bunyala irrigation scheme is the highest performing rice irrigation scheme in western Kenya. The three irrigation schemes have an average performance. Operation and management measures to improve the current performance of the irrigation schemes are needed.
\end{abstract}

Keywords: benchmarking; evaluation of performance; performance indicator; principal component analysis

\section{Introduction}

Irrigated agriculture occupies 4 percent of the total land area (2.9 million ha) under agriculture in Kenya [1]. It accounts for 3 percent of the Kenya's gross domestic product (GDP) and 18 percent of the total value of all agricultural produce [1]. The main irrigated crops in Kenya are rice, wheat, maize, vegetables, coffee, fruits, sugarcane, cotton and horticulture [2]. Rice is the third main cereal crop grown in Kenya after maize and wheat [3]. It is mainly grown in government-established irrigation schemes managed by National Irrigation Board (NIB). These are Ahero, Bunyala, West Kano irrigation schemes located in Western Kenya and Mwea irrigation scheme in Central Kenya. The other NIB-managed irrigation schemes are: Hola, Perkerra, Bura and, more, recently the Galana-Kulalu Food Security Project [4]. The continuous flooding method of water application is used in rice farming in Ahero, West Kano, Bunyala and Mwea. This system of rice farming utilises a lot of water, and production is highly reduced during drought periods [5]. Rice production in Kenya is below demand, and the gap is filled through imports. Currently, 54,000 metric tonnes of milled rice are produced in Kenya, whereas the current national demand for rice is 693,000 metric tonnes [6]. Rice consumption is expected to increase 
due to rising population, change in eating habits and urbanisation [3]. The population in Kenya has been growing rapidly, with an increase from 28.7 million in 1999 to 38.6 million in 2009, and is expected to reach 69.5 million by 2030 [4,7]. Increased demand for food and competition for water among various sectors of the economy is therefore expected. Kenya is a water-scarce country with access to 647 cubic metres of freshwater per capita per annum. This is way below the international acceptable levels of 1000 cubic metres per capita per annum [8]. Water scarcity limits water available for irrigation. Efficient utilisation of water, land and other resources increases productivity and promotes sustainable development in irrigated agriculture.

The inefficient water use, and the variable and low productivity of public irrigation schemes in Kenya is a major concern. Heavy investment is channelled into these irrigation schemes, but their productivity is below the expectation [2]. In addition, poor productivity of public irrigation schemes in Kenya hinders their expansion [9]. There is therefore a need to improve productivity and increase the efficiency of the utilisation of water and other resources. Comparative evaluation of performance using the benchmarking tool can be applied. Benchmarking is a tool used for evaluating performance of irrigation systems over time and comparing the performance with comparable irrigation systems or own set goals [10]. Comparative performance evaluation of irrigation systems enables identification of the performance gap between current and best practices [11]. The benchmarking tool was developed by the International Programme for Technology and Research in Irrigation and Drainage (IPTRID) as a management tool for improving productivity and efficiency in the irrigation and drainage sector [12]. The IPTRID, the Food and Agriculture Organisation (FAO), the World Bank, the International Water Management Institute (IWMI) and the International Commission on Irrigation and Drainage (ICID) have laid an emphasis on measuring performance in the irrigation and drainage sector as a way of achieving sustainable development in agriculture. Evaluation of the performance of irrigation schemes is based on standard performance indicators. A performance indicator is a description of actual achievement in relation to one of the goals set in an irrigation system [10]. Performance indicators can be categorised into either internal or external indicators.

External indicators examine inputs and outputs of an irrigation system [13]. The indicators describe the overall performance of irrigation systems using ratios that compare inputs to outputs. These indicators give an expression of various efficiencies related to water, budgets or yields. External indicators do not provide an insight into what should be done to improve performance. They only give an indication that improvement is needed [14]. IPTRID benchmarking indicators fall in the category of external indicators [14]. External indicators are suitable for use in cross-comparison of the performance of irrigation systems [15]. Internal indicators, on the other hand, examine the internal processes of the system and the level of water delivery service provided by the project. The indicators look into operations, hardware of the system, institutional and management set up, and water distribution and delivery [13]. Internal indicators provide an insight into what should be done to improve performance. This study was based on cross-comparison of the irrigation schemes and only external indicators were used.

Evaluation of performance of western Kenyan rice irrigation schemes was done using benchmarking indicators and principal component analysis (PCA). Comparison of performance indicators does not provide a clear picture of the overall performance of one irrigation scheme relative to others. Therefore, other tools are required when measuring the overall performance. The efficiency of nine irrigation districts in Andalusia, Spain was evaluated using performance indicators and multivariate data analysis (cluster analysis and principal component analysis) [16]. The study used principal component analysis to develop quality index for detecting performance weakness of the various irrigation districts. Also, [17] applied agglomerative hierarchical cluster analysis to group water users association (WUAs) and compared the performance of drip and sprinkler irrigation systems using performance indicators. Hierarchical cluster analysis (HCA) and data envelop analysis (DEA) was used in evaluating efficiency of performance of seventeen small and three large irrigation schemes along Senegal Valley, Mauritania [18]. The irrigation schemes were grouped into three groups 
using hierarchical cluster analysis and only four irrigation schemes with an average land productivity of $4.75 \mathrm{ton} /$ ha were found to be technically efficient.

\section{Principal Component Analysis (PCA)}

Principal component analysis is a statistical multivariate technique that uses orthogonal transformation to convert several correlated observed variables into a smaller number of linearly uncorrelated variables known as principal components [19]. The first principal component accounts for the highest variation in data and the subsequent component has the highest variance possible, as long as it is orthogonal to the preceding component. The number of $p$ original features is reduced into a few unobserved variables, $k$ known as principal components. The principal components $(k)$ account for the maximum variance such that $k \leq p$ [20]. Original features $p$ represents the original number of observed variables for each of the case $(1-n)$ before transformation. An example of original data with $n$ objects and $p$ observed variables is presented in Table 1.

Table 1. Form of data for Principal component analysis with $n$ cases each with $p$ features.

\begin{tabular}{cccc}
\hline Case & $\boldsymbol{X}_{\mathbf{1}}$ & $\cdot$ & $\boldsymbol{X}_{\boldsymbol{p}}$ \\
\hline 1 & $X_{11}$ & $\cdot$ & $X_{1 p}$ \\
2 & $X_{21}$ & $\cdot$ & $X_{2 p}$ \\
$\cdot$ & $\cdot$ & $\cdot$ & $\cdot$ \\
$\cdot$ & $\cdot$ & $\cdot$ & $\cdot$ \\
$n$ & $X_{n 1}$ & $\cdot$ & $X_{n p}$ \\
\hline
\end{tabular}

The principal components $\left(Z_{1}, Z_{2}, \ldots, Z_{i}\right)$ are generated through linear combination of variables $X^{\prime}$ s.

$$
Z=\alpha^{T} X
$$

where; $Z=Z_{1}, Z_{2}, Z_{p}$-vector of principal components; $\alpha^{T}$-matrix of coefficients $\alpha_{i j}$ for $i, j=1,2, \ldots, p$

$$
Z_{1}=\alpha_{11} X_{1}+\alpha_{12} X_{2}+\ldots+\alpha_{1 p} X_{p}
$$

$Z_{1}$ is the largest combination of $p$ features under the condition that

$$
\alpha_{11}^{2}+\alpha_{12}^{2}+\ldots+\alpha_{1 p}^{2}=1
$$

The second principle component $Z_{2}$ has the second-largest possible variance in $X_{1}, X_{2}, \ldots, X_{p}$, which is orthogonal and uncorrelated with $Z_{1}$. The $j^{\text {th }}$ principal component with the largest possible variance is defined similarly, provided it is uncorrelated with the $i^{\text {th }}$ principal component for $i<j$. The principal components obtained are in decreasing order, i.e., variance $\left(Z_{1}\right)>$ variance $\left(Z_{2}\right)>\ldots>$ variance $\left(Z_{p}\right)$. If $\lambda_{i}$ is the variance (eigenvalue) for $Z_{i}$ and $\alpha_{i j}$ is the eigenvector for $Z_{i}$ then the following conditions hold:

$$
\begin{gathered}
\lambda_{1} \geq \lambda_{2} \geq \lambda_{i} \geq 0 \\
\alpha_{1}^{T} \alpha_{i}=1 \\
\alpha_{1}^{T} \alpha_{h}=0
\end{gathered}
$$

The eigenvalue represents the level of variation caused by the associated principal component. The variance for the principal component for k-retained principle components is computed by

$$
t_{k}=\frac{\sum_{i=1}^{k} \lambda_{i}}{\sum_{i=1}^{p} \lambda_{i}}
$$


Principal components can be extracted using covariance or correlation matrix. Covariance matrix is applied where the variables do not have gross variance. For such data, standardisation of data should be done prior to using a covariance matrix. The correlation matrix, on the other hand, is applied to data with a wide variance [19]. It is suitable for analysis of variables with different measurement scales, and no prior transformation is needed. Use of the correlation matrix is not possible for data with small variance [19]. The researcher chooses the appropriate transformation matrix based on the data structure. When using the correlation matrix, only principal components with eigenvalues greater than 1 are retained. Principal components with eigenvalues greater than the average of total eigenvalues are retained when the covariance matrix is used [20]. PCA is objective and relies on the underlying data structure to generate non-subjective weights [21].

The combination of benchmarking indicators and PCA in this study enabled the description of performance using a single performance score. The performance score gives a measure of the level of performance of an individual irrigation scheme relative to the others. This study provides information to scheme managers on areas of weakness that require improvement. Furthermore, it sheds some light for stakeholders and policy makers on areas that require policy interventions.

\section{Materials and Methods}

\subsection{Description of Study Area}

The study was carried out in the Ahero, West Kano and Bunyala irrigation schemes in western Kenya managed by National Irrigation Board NIB (Figure 1). Rice is the main crop grown in these schemes. In all the schemes, water is abstracted using electric-powered pumps, conveyed with open earth canals and applied using basin irrigation method. Drain water is pumped back to Lake Victoria in the West Kano irrigation scheme because the outlet is on lower ground than the lake. The schemes have no gauging stations. Western Kenya is hot and humid, with a bimodal rainfall pattern. The schemes are underlain by deep black cotton soils [22].

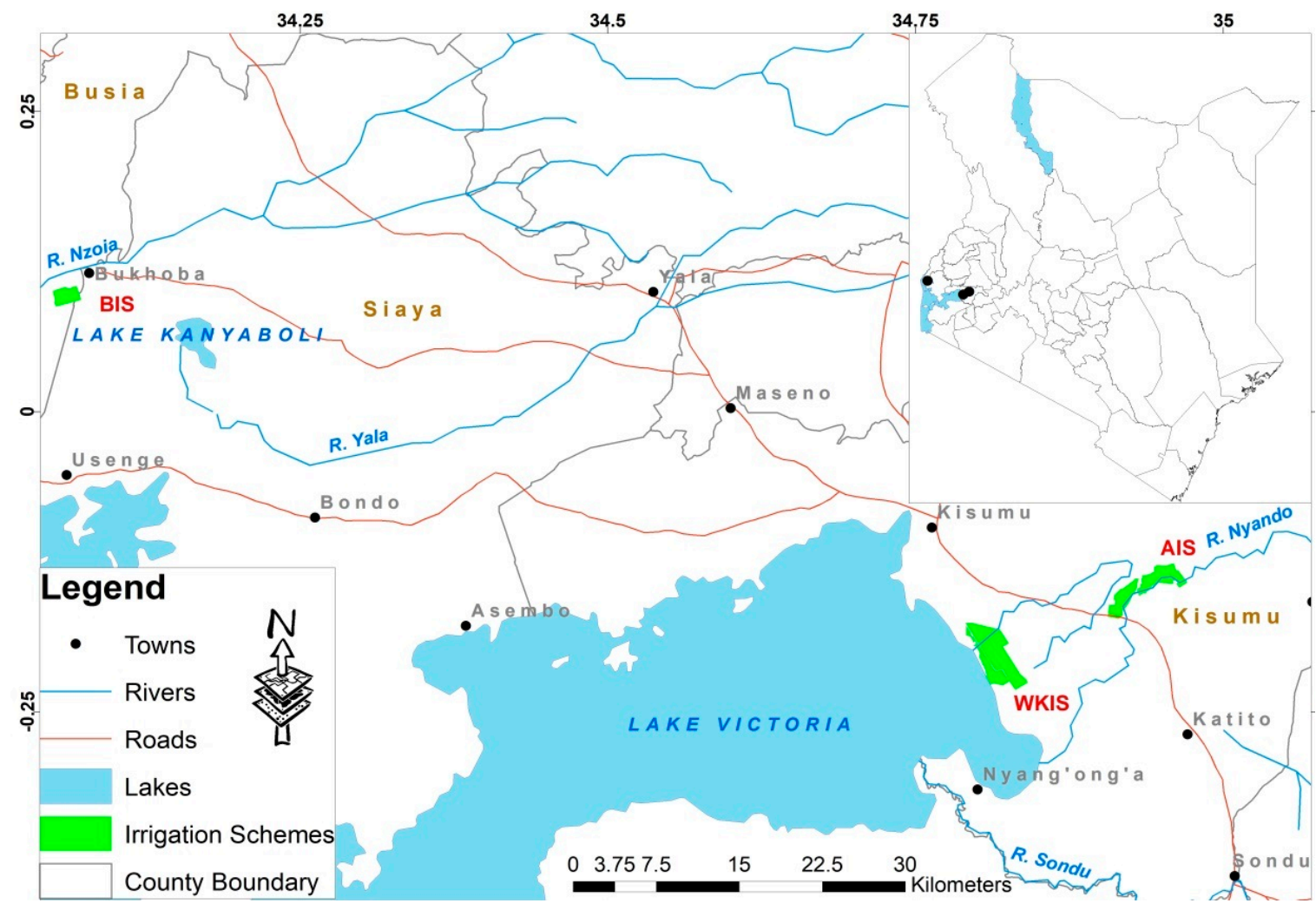

Figure 1. Study Area. 
A detailed description of the main features of three irrigation schemes studied is presented in Table 2.

Table 2. Main characteristics of irrigation schemes benchmarked in western Kenya.

\begin{tabular}{|c|c|c|c|}
\hline \multirow{2}{*}{ Description } & \multicolumn{3}{|c|}{ Irrigation Scheme } \\
\hline & Ahero & West Kano & Bunyala \\
\hline Command area (ha) & 900 & 980 & 728 \\
\hline Latitude & $00^{\circ} 10^{\prime}$ South & $\begin{array}{l}\text { Between } 00^{\circ} 04^{\prime} \text { South and } \\
00^{\circ} 20^{\prime} \text { South }\end{array}$ & $00^{\circ} 06^{\prime}$ North \\
\hline Longitude & $34^{\circ} 58^{\prime}$ East & $\begin{array}{l}\text { Between } 34^{\circ} 48^{\prime} \text { East and } \\
35^{\circ} 02^{\prime} \text { East }\end{array}$ & $34^{\circ} 04^{\prime}$ East \\
\hline Location & Kano plains, Kisumu county & Kano plains, Kisumu county & Kisumu/Siaya county \\
\hline Land ownership & Government & Government & Government and private \\
\hline Main crops & $\begin{array}{l}\text { Rice, Soybeans, maize, } \\
\text { Watermelon, sorghum }\end{array}$ & Rice, sorghum, maize & Rice, pulses and horticulture \\
\hline Number of seasons & $\begin{array}{l}2 \text { seasons } \\
\text { 1st season-rice } \\
\text { 2nd-other crop }\end{array}$ & $\begin{array}{l}2 \text { seasons } \\
\text { 1st season-rice } \\
\text { 2nd-other crop }\end{array}$ & $\begin{array}{l}2 \text { seasons } \\
\text { 1st season-rice } \\
\text { 2nd-other crop }\end{array}$ \\
\hline Number of farmers & 556 & 845 & 1934 \\
\hline Farm size (acres) & $1-4$ & $2-4$ & $1-5$ \\
\hline Water source & $\begin{array}{l}\text { Surface water } \\
\text { River Nyando }\end{array}$ & $\begin{array}{l}\text { Surface water } \\
\text { Lake Victoria }\end{array}$ & $\begin{array}{l}\text { Surface water } \\
\text { River Nzoia }\end{array}$ \\
\hline Type of water distribution & On demand & On demand & On demand \\
\hline Method of water abstraction & $\begin{array}{l}\text { Pumping using electricity } \\
2 \text { pumps each } 1100 \mathrm{~L} / \mathrm{s} \\
2 \text { pumps each } 650 \mathrm{~L} / \mathrm{s}\end{array}$ & $\begin{array}{l}\text { Pumping using electricity } \\
3 \text { pumps each } 750 \mathrm{~L} / \mathrm{s}\end{array}$ & $\begin{array}{l}\text { Pumping using electricity } \\
4 \text { pumps each } 300 \mathrm{~L} / \mathrm{s}\end{array}$ \\
\hline Water delivery infrastructure & Open earth canals & Open earth canals & Open earth canals \\
\hline $\begin{array}{l}\text { Type of water control } \\
\text { equipment }\end{array}$ & None & None & None \\
\hline $\begin{array}{l}\text { Discharge measurement } \\
\text { facilities }\end{array}$ & None & None & None \\
\hline Irrigation system & Surface-Basin & Surface-Basin & Surface-Basin \\
\hline Water availability & $\begin{array}{l}\text { Sufficient-occasionally } \\
\text { not sufficient }\end{array}$ & Abundant & Abundant \\
\hline Type of surface drain & $\begin{array}{l}\text { Open earth channel } \\
\text { by gravity }\end{array}$ & $\begin{array}{l}\text { Pumped through open } \\
\text { earth channel. } \\
\text { Using four } 500 \mathrm{~L} / \mathrm{s} \\
\text { outlet pumps. }\end{array}$ & Open earth channel \\
\hline Type of revenue collection & Charge on irrigated area & Charge on irrigated area & Charge on irrigated area \\
\hline
\end{tabular}

\subsection{Data Collection}

Secondary time series data for five years (2012-2016) was obtained from records kept by management of the various irrigation schemes. The data collected was only for rice production. Rice is grown in the first season, while the other crops are grown in the second season. The production of the other crops has not been formalised, and their production is not documented. Data on total yield per season, local crop price per season, cropped area, total command area, revenue collected, expected revenue, cost of production, water supplied, pump speed, and pumping hours was collected from records kept by the irrigation scheme offices and field survey. Meteorological data was obtained from Ahero research station, West Kano weather station, the Kenya Meteorological Department (KMD) and the NASA POWER Centre. Key informant interviews, observation, and focus group discussion methods were used to collect data on farming practices, cropping pattern, status of the irrigation systems and maintenance of the system. 


\subsection{Data Analysis}

Field data was first processed to obtain variables for calculating performance indicators. The variables were computed as follows:

(a) Crop water requirement

Crop pattern, transplanting date and weather data was used in calculating rice crop water demand and crop irrigation water requirement using CROPWAT 8.0 software (developed by FAO, Rome, Italy). Computation of reference crop water demand $\left(E T_{0}\right)$ is based on the Penman Monteith equation. The effective rainfall was computed using USDA-Soil Conservation Method, in-built in CROPWAT 8. Number of sunshine hours, temperature, humidity, rainfall data, wind speed, soil type, transplanting date and crop pattern were used as input for the model. The total annual volume of water consumed by all crops in the irrigation schemes was computed using Equation (8) [10].

$$
V E t_{c}=\sum_{c r o p s} E t_{c} \times A
$$

$V E t_{c}=$ Total volume of crop water demand $\left(\mathrm{m}^{3}\right) ; E t_{c}=$ crop evapotranspiration from planting to harvesting $\left(\mathrm{m}^{3}\right) ; A=$ cropped area.

Total annual volume crop irrigation demand was then calculated using Equation (9) [10].

$$
V E t_{N e t}=I R_{n} A
$$

$V E t_{N e t}=$ Total volume of water consumed by crops less effective rainfall $\left(\mathrm{m}^{3}\right) ; I R_{n}=$ net irrigation water requirement $\left(\mathrm{m}^{3}\right) ; A=$ cropped area

(b) Total annual volume of irrigation water supply $\left(\mathrm{m}^{3}\right)$. This was obtained by summing the daily volume of water pumped for the rice growing season in each year. Daily volume of water pumped was obtained as the product of pump efficiency, pumping hours and the pump operating speed.

(c) Total annual volume of water supply $\left(\mathrm{m}^{3}\right)$. This was obtained by summing the total volume of water pumped for irrigation and total effective rainfall for the rice growing season in a year. The effective rainfall was computed using the USDA-Soil Conservation Method, in-built in CROPWAT 8. The effective rainfall in terms of depth was converted into volume by multiplying by the total annual cropped area.

(d) Total annual cropped area (ha). This was calculated by summing up all the area under rice crop in each year.

(e) Total command area of the system (ha). This is the net area serviced by the scheme less the right of way for canals, drains, roads and villages. It was obtained from the design office of each irrigation scheme.

The performance indicators used were obtained from the IPTRID benchmarking indicators presented in Table 3 [10].

Table 3. Proposed key performance indicators.

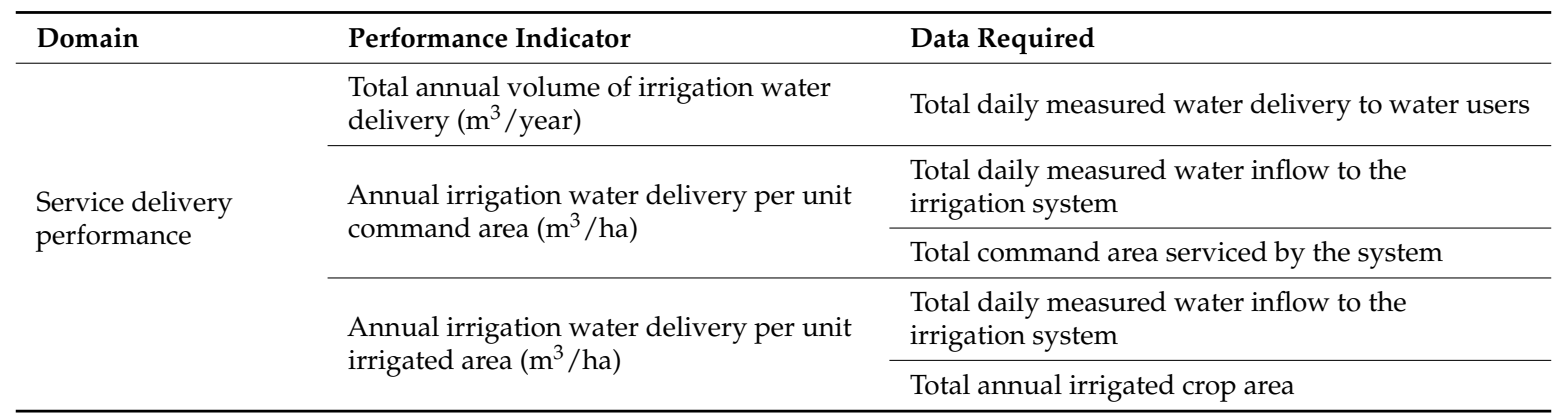


Table 3. Cont

\begin{tabular}{|c|c|c|}
\hline Domain & Performance Indicator & Data Required \\
\hline & \multirow[b]{2}{*}{ Main system water delivery efficiency } & Total daily measured water delivery to water users \\
\hline & & $\begin{array}{l}\text { Total daily measured water inflow to the } \\
\text { irrigation system }\end{array}$ \\
\hline & \multirow{3}{*}{ Annual relative water supply } & $\begin{array}{l}\text { Total daily measured water inflow to the } \\
\text { irrigation system }\end{array}$ \\
\hline & & Total daily measured rainfall over irrigated area \\
\hline & & $\begin{array}{l}\text { Total daily/periodic volume of crop water demand, } \\
\text { including percolation losses for rice crops }\end{array}$ \\
\hline & \multirow[b]{2}{*}{ Annual relative irrigation supply } & $\begin{array}{l}\text { Total daily measured water inflow to the } \\
\text { irrigation system }\end{array}$ \\
\hline & & $\begin{array}{l}\text { Total daily/periodic volume of irrigation water } \\
\text { demand (crop water demand excluding effective } \\
\text { rainfall), including percolation losses for rice }\end{array}$ \\
\hline & \multirow{2}{*}{ Water delivery capacity } & Current main canal capacity \\
\hline & & Peak month irrigation water demand \\
\hline & \multirow{2}{*}{ Security of entitlement supply } & System water entitlement \\
\hline & & 10 years minimum water availability flow pattern \\
\hline \multirow{14}{*}{ Financial performance } & \multirow[b]{2}{*}{ Cost recovery ratio } & Total revenues collected from water users \\
\hline & & $\begin{array}{l}\text { Total management, operation and maintenance } \\
\text { (MOM) cost }\end{array}$ \\
\hline & \multirow{2}{*}{ Maintenance cost to revenue ratio } & Total maintenance expenditure \\
\hline & & Total revenue collected from water users \\
\hline & \multirow{2}{*}{ Total MOM cost per unit area (US\$/ha) } & $\begin{array}{l}\text { Total management, operation and } \\
\text { maintenance expenditure }\end{array}$ \\
\hline & & Total command area serviced by the system \\
\hline & \multirow{2}{*}{$\begin{array}{l}\text { Total cost per person employed on water } \\
\text { delivery (US\$ / person) }\end{array}$} & Total cost of MOM personnel \\
\hline & & Total number of MOM personnel employed \\
\hline & \multirow{2}{*}{ Revenue collection performance } & Total revenues collected from water users \\
\hline & & Total service revenue due \\
\hline & \multirow{2}{*}{$\begin{array}{l}\text { Staffing numbers per unit area } \\
\text { (persons/ha) }\end{array}$} & Total number of MOM personnel employed \\
\hline & & Total command area serviced by system \\
\hline & \multirow{2}{*}{$\begin{array}{l}\text { Average revenue per cubic meter of } \\
\text { irrigation water supplied }\left(\mathrm{US} \$ / \mathrm{m}^{3}\right)\end{array}$} & Total revenues collected from water users \\
\hline & & Total daily measured water delivery to water users \\
\hline \multirow{12}{*}{$\begin{array}{l}\text { Agricultural } \\
\text { Productive efficiency }\end{array}$} & $\begin{array}{l}\text { Total gross annual agricultural } \\
\text { production (tones) }\end{array}$ & Total tonnage produced under each crop \\
\hline & $\begin{array}{l}\text { Total annual value of agricultural } \\
\text { production (US\$) }\end{array}$ & Total annual tonnage of each crop \\
\hline & \multirow{4}{*}{ Output per unit serviced area (US\$/ha) } & Crop market price \\
\hline & & Total annual tonnage of each crop \\
\hline & & Crop market price \\
\hline & & Total command area serviced by system \\
\hline & \multirow{3}{*}{ Output per unit irrigated area (US\$/ha) } & Total annual tonnage of each crop \\
\hline & & Crop market price \\
\hline & & Total annual irrigated crop area \\
\hline & \multirow{3}{*}{$\begin{array}{l}\text { Output per unit irrigation supply } \\
\left(\mathrm{US} \$ / \mathrm{m}^{3}\right)\end{array}$} & Total annual tonnage of each crop \\
\hline & & Crop market price \\
\hline & & $\begin{array}{l}\text { Total daily measured water inflow to the } \\
\text { irrigation system }\end{array}$ \\
\hline
\end{tabular}


Table 3. Cont.

\begin{tabular}{|c|c|c|}
\hline Domain & Performance Indicator & Data Required \\
\hline & \multirow{3}{*}{$\begin{array}{l}\text { Output per unit water consumed } \\
\left(\mathrm{US} \$ / \mathrm{m}^{3}\right)\end{array}$} & Total annual tonnage of each crop \\
\hline & & Crop market price \\
\hline & & Total volume of water consumed by the crops $\left(E T_{c}\right)$ \\
\hline \multirow{15}{*}{$\begin{array}{l}\text { Environmental } \\
\text { performance }\end{array}$} & \multirow{3}{*}{ Water quality: Salinity (mmhos/cm) } & $\begin{array}{l}\text { Total daily measured water inflow to the irrigation } \\
\text { system }\end{array}$ \\
\hline & & $\begin{array}{l}\text { Electrical conductivity of periodically collected } \\
\text { drainage water samples }\end{array}$ \\
\hline & & $\begin{array}{l}\text { Total daily measured drainage water outflow from } \\
\text { the irrigation system }\end{array}$ \\
\hline & \multirow{4}{*}{ Water quality: Biological (mg/litre) } & $\begin{array}{l}\text { Biological load of periodically collected irrigation } \\
\text { water samples }\end{array}$ \\
\hline & & $\begin{array}{l}\text { Total daily measured water inflow to the } \\
\text { irrigation system }\end{array}$ \\
\hline & & $\begin{array}{l}\text { Biological load of periodically collected drainage } \\
\text { water samples }\end{array}$ \\
\hline & & $\begin{array}{l}\text { Total daily measured drainage water outflow from } \\
\text { the irrigation system }\end{array}$ \\
\hline & \multirow{4}{*}{ Water quality: Chemical (mg/litre) } & $\begin{array}{l}\text { Chemical load of periodically collected irrigation } \\
\text { water samples }\end{array}$ \\
\hline & & $\begin{array}{l}\text { Total daily measured water inflow to the } \\
\text { irrigation system }\end{array}$ \\
\hline & & $\begin{array}{l}\text { Chemical load of periodically collected drainage } \\
\text { water samples }\end{array}$ \\
\hline & & $\begin{array}{l}\text { Total daily measured drainage water outflow from } \\
\text { the irrigation system }\end{array}$ \\
\hline & Average depth to water table (m) & Periodic depth measurement to water table \\
\hline & Change in water table depth over time $(\mathrm{m})$ & $\begin{array}{l}\text { Periodic depth measurement to water table over } 5 \\
\text { year period }\end{array}$ \\
\hline & \multirow{2}{*}{ Salt balance (tones) } & $\begin{array}{l}\text { Periodic measurement of salt content of } \\
\text { irrigation water }\end{array}$ \\
\hline & & $\begin{array}{l}\text { Periodic measurement of salt content of } \\
\text { drainage water }\end{array}$ \\
\hline
\end{tabular}

The methodology adopted entails: (i) selection of suitable indicators to describe performance of the irrigation schemes; (ii) combining the indicators into a single performance score using principal component analysis. Some of the proposed key performance indicators (Table 3) were not computed because of lack of data.

\subsubsection{Performance Indicators}

Fourteen performance indicators were computed as shown in Table 4. The indicator values were compared among the three schemes in each year.

To allow for global comparison, the total value of agricultural production is converted into gross value of production using Equation (10).

$$
G V P=\left\lfloor\sum \operatorname{crops} A_{i} Y_{i}\right\rfloor \text { MU currency exchange rate }
$$

GVP-gross value of production; $A_{i}$-area cropped with crop $i ; Y_{i}$ - the yield of crop $i ; P_{i}$-local price of crop $i$; $M U$-currency exchange rate (US\$ per unit local currency). 
Table 4. Computation of performance indicators.

\begin{tabular}{|c|c|}
\hline Performance Indicator & Definition/Calculation \\
\hline Total annual volume irrigation supply & Total annual volume of irrigation water pumped or diverted \\
\hline \multirow{2}{*}{ Annual relative water supply } & total annual volume of water supply \\
\hline & $\overline{\text { total annual volume of crop water demand }}$ \\
\hline \multirow{2}{*}{ Annual relative irrigation supply } & total annual volume of irrigation supply \\
\hline & total annual volume of crop irrigatio demand \\
\hline \multirow{2}{*}{ Annual irrigation supply per unit irrigated area $\left(\mathrm{m}^{3} / \mathrm{ha}\right)$} & Total annual volume of irrigation supply \\
\hline & Total annual irrigated area \\
\hline \multirow{2}{*}{ Annual irrigation supply per unit command area $\left(\mathrm{m}^{3} / \mathrm{ha}\right)$} & Total annual volume of irrigation supply \\
\hline & Total annual command area \\
\hline Total gross annual agricultural production (tones) & Total annual tonnage of each crop \\
\hline Total annual valueof agricultural production (US\$) & Total annual gross value of production (GVP) received by producers \\
\hline \multirow{2}{*}{ Output per unit irrigated area (US\$/ha) } & Total annual value of agricultural production \\
\hline & Total annual irrigated area \\
\hline \multirow{2}{*}{ Output per unit command area (US\$/ha) } & Total annual value of agricultural production \\
\hline & Total command area \\
\hline \multirow{2}{*}{ Output per unit water supply (US\$ $/ \mathrm{m}^{3}$ ) } & Total annual value of agricultural production \\
\hline & total annual volume of water suply \\
\hline \multirow{2}{*}{ Output per unit irrigation supply (US\$ $/ \mathrm{m}^{3}$ ) } & Total annual value of agricultural production \\
\hline & total annual volume of irrigation suply \\
\hline \multirow{2}{*}{ Output per unit crop water demand $\left(\mathrm{US} \$ / \mathrm{m}^{3}\right)$} & Total annual value of agricultural production \\
\hline & total annual volume of crop water demand \\
\hline \multirow{2}{*}{ Water fee collection performance (\%) } & Gross revenue collected $\times 100$ \\
\hline & Gross revenue invoiced $\times 100$ \\
\hline \multirow{2}{*}{ Average revenue per unit irrigation supply $\left(\mathrm{US} \$ / \mathrm{m}^{3}\right)$} & total annual revenue collected \\
\hline & Total annual volume of irrigation supply \\
\hline
\end{tabular}

\subsubsection{Calculation of Overall Irrigation Scheme Performance}

The overall scheme performance was determined by computing a single performance score. The total volume of irrigation water supply, total annual agricultural production and total annual value of agricultural production indicators were excluded in the computation of overall performance score. These indicators are based on extensive scale rather than relative scale and their inclusion might distort the results. Indicators were first tested for statistical correlation using the Pearson correlation method. Ten indicators with low correlation were selected. The indicators were weighted using principal component analysis, then normalised using the reference to target method and finally aggregated into a single performance score using the linear aggregation method. Weighting of indicators was done using PCA.

\section{Principal Component Analysis (PCA)}

PCA was done using SPSS windows version16 software. Prior to PCA, the data was tested for suitability using Kaiser-Meyer-Olklin (KMO) and Bartlett Test of Sphericity (BTS). The extracted components were rotated using orthogonal varimax method to achieve significant components. The indicator weights were computed using rotated factor loadings and eigenvalues, as shown in Equation (11).

$$
W_{k}=\sum_{j=1}^{j=n} \frac{\left(\text { Factor loading }_{k j}\right)^{2}}{\text { eigenvalue }_{j}} \times \frac{\text { eigenvalue }_{j}}{\sum_{j=1}^{j=n} \text { eigenvalue }_{j}}
$$

Factor loading $k_{j}$ - factor loading of indicator $k$ in the principal component $j$; eigenvalue ${ }_{j}$ - eigenvalue for $j^{\text {th }}$ principal component $j=1, j=2, \ldots, j=n$ the extracted principal components with an eigenvalue above 1 . 
The indicators were normalised using reference to target using Equation (12).

$$
I_{q s}^{t}=\frac{x_{q s}^{t}}{x_{b}}
$$

$I_{q s}^{t}=$ normalised value of indicator $q$ for scheme $s$ at time $t ; x_{q s}^{t}=$ indicator value for scheme $s$ at time $t$; $x_{b}=$ threshold value for indicator value.

The threshold values used for normalisation of indicators are shown in Table 5.

Table 5. Indicative threshold values.

\begin{tabular}{lcc}
\hline \multicolumn{1}{c}{ Performance Indicator } & Threshold Values & Reference \\
\hline Relative water supply & 2 & {$[23]$} \\
Relative irrigation supply & 2 & {$[23]$} \\
Annual irrigation water delivery per unit irrigated area & $450-700 \mathrm{~mm}$ & {$[24]$} \\
Annual irrigation water delivery per unit command area & $450-700 \mathrm{~mm}$ & {$[24]$} \\
Output per unit irrigated area & $3.8 \mathrm{ton} / \mathrm{ha}$ & {$[25]$} \\
Output per unit command area & $3.8 \mathrm{ton} / \mathrm{ha}$ & {$[25]$} \\
Output per unit irrigation supply & $2 \mathrm{~kg} / \mathrm{m}^{3}$ & {$[26]$} \\
Output per unit water supply & $2 \mathrm{~kg} / \mathrm{m}^{3}$ & {$[26]$} \\
Output per water consumed & $2 \mathrm{~kg} / \mathrm{m}^{3}$ & {$[26]$} \\
Water fee collection performance & $100 \%$ & {$[10]$} \\
Average revenue per unit irrigation supply & $7.5 \mathrm{US} \mathrm{dollar} \mathrm{cents}$ & {$[27]$} \\
\hline
\end{tabular}

A single performance score was finally computed using Equation (13).

$$
C I_{s t}=\sum_{k=1}^{k=n} W_{k} I_{k s}
$$

where; $W_{k}=$ indicator weight; $I_{k s}=$ normalised indicator $k$ for scheme $\mathrm{s} ; C I_{s \mathrm{t}}=$ performance score for irrigation scheme $s$ at time $t$.

\section{Results and Discussion}

The results of comparative evaluation of performance using performance indicators are presented as follows.

\subsection{Water Supply Performance}

The indicators under this category give a measure of water supply relative to demand. Water abundance or scarcity of water can be deduced from these indicators [28]. The results of water supply indicators are presented in Table 6. The command area and irrigated area used in computation of various performance indicators for each scheme is also presented in Table 6.

The available irrigable area (command area) in all the schemes has not been fully exploited. Some of the command area is not irrigated due to the inability of farmers to acquire farming inputs. Irrigated area in Ahero and Bunyala irrigation schemes is close to command area. The low irrigated area in West Kano in 2013 and 2014 can be attributed to lack of interest in irrigation by farmers following the collapse of the revolving fund committee. The annual volume of irrigation supply for the schemes ranges between 2.2 and $8.4 \mathrm{MCM}$. All the schemes divert water by pumping using electricity. The amount of water abstracted at any given time depends on cropped area. The irrigation schemes have a high fluctuation in the amount of water supplied due to frequent power outages experienced in the region. The amount of water abstracted is estimated using pumping hours recorded, pump speed and pumping efficiency. The amount of water delivered to irrigation blocks could not be computed. 
Table 6. Water supply indicators.

\begin{tabular}{|c|c|c|c|c|c|c|c|c|}
\hline $\begin{array}{l}\text { Irrigation } \\
\text { Scheme }\end{array}$ & Year & $\begin{array}{l}\text { Command } \\
\text { Area (ha) }\end{array}$ & $\begin{array}{l}\text { Total Annual } \\
\text { Irrigated Area } \\
\text { (ha) }\end{array}$ & $\begin{array}{l}\text { Total Annual Volume } \\
\text { of Irrigation Water } \\
\text { Supply }\left(\mathrm{m}^{3}\right)\end{array}$ & RWS & RIS & $\begin{array}{c}\text { Annual Water Deliver } \\
\text { per Unit Irrigated Area } \\
\left(\mathrm{m}^{3} / \mathrm{ha}\right)\end{array}$ & $\begin{array}{c}\text { Annual Water Delivery } \\
\text { per Unit Command } \\
\text { Area }\left(\mathrm{m}^{3} / \mathrm{ha}\right)\end{array}$ \\
\hline \multirow{5}{*}{ Ahero } & $2012 / 2013$ & 900 & 877 & $6,827,820$ & 1.98 & 2.15 & 7785 & 7586 \\
\hline & $2013 / 2014$ & 900 & 846 & $4,938,460$ & 1.14 & 0.86 & 5837 & 5487 \\
\hline & $2014 / 2015$ & 900 & 783 & $4,867,840$ & 1.45 & 1.31 & 6217 & 5409 \\
\hline & $2015 / 2016$ & 900 & 824 & $4,362,330$ & 1.28 & 0.86 & 5294 & 4847 \\
\hline & $2016 / 2017$ & 900 & 720 & $3,950,460$ & 1.24 & 0.68 & 5487 & 4389 \\
\hline \multirow[t]{2}{*}{ Average } & & & 810 & $4,989,382$ & 1.42 & 1.17 & 6124 & 5544 \\
\hline & $2012 / 2013$ & 980 & 617 & $6,934,097$ & 2.31 & 3.38 & 11,238 & 7076 \\
\hline \multirow{4}{*}{ West Kano } & $2013 / 2014$ & 980 & 206 & $2,540,691$ & 1.94 & 1.64 & 12,310 & 2593 \\
\hline & $2014 / 2015$ & 980 & 196 & $2,223,590$ & 2.21 & 2.74 & 11,376 & 2269 \\
\hline & $2015 / 2016$ & 980 & 650 & $7,115,034$ & 1.92 & 1.75 & 10,955 & 7260 \\
\hline & $2016 / 2017$ & 980 & 690 & $8,411,680$ & 1.86 & 1.58 & 12,191 & 8583 \\
\hline Average & & & 472 & $5,445,018$ & 2.05 & 2.22 & 11,614 & 5556 \\
\hline \multirow{5}{*}{ Bunyala } & $2012 / 2013$ & 728 & 701 & $4,406,847$ & 1.98 & 1.94 & 6287 & 6050 \\
\hline & $2013 / 2014$ & 728 & 701 & $6,215,776$ & 2.17 & 2.25 & 8868 & 8533 \\
\hline & $2014 / 2015$ & 728 & 701 & $5,401,296$ & 2.06 & 2.26 & 7706 & 7415 \\
\hline & $2015 / 2016$ & 728 & 625 & $5,387,886$ & 2.24 & 2.40 & 8622 & 7396 \\
\hline & $2016 / 2017$ & 728 & 666 & $8,077,590$ & 2.44 & 2.46 & 12,130 & 11,089 \\
\hline Average & & & 679 & $5,897,879$ & 2.18 & 2.26 & 8723 & 8097 \\
\hline
\end{tabular}

RWS-Relative Water Supply; RIS-Irrigation Water Supply. 
The relative irrigation supply (RIS) values varied from 0.68 to 3.38 during the study period. RIS and RWS values should be above 1 . This is because irrigation efficiency is always below $100 \%$ due to unavoidable conveyance and application losses. Values below 1 indicate water deficit [26,27]. The average RIS in the Ahero, west Kano and Bunyala irrigation schemes was 1.17, 2.22 and 2.26, respectively. A low RIS value of 0.4 was reported in Muda irrigation scheme, Malaysia [15]. The low RIS was associated with the use of real-time monitoring of water depth in rice farms, which enabled effective use of rainfall. The relative water supply (RWS) varied between 1.14 and 2.44 for all the schemes. RWS above 2 shows that the amount of water supplied is adequate [15]. High RIS and RWS values in the West Kano and Bunyala irrigation schemes show that there is adequate supply of water. The Ahero irrigation scheme suffers from inadequate supply of water, which is evident from the low RIS values, the majority of which are below 1 . The Ahero irrigation scheme draws water from the river Nyando, which is occasionally affected by drought and siltation. The Ahero irrigation scheme was in drought, which lowered the amount of water available for irrigation in 2013. In 2016, one of the water pumps, with a discharge capacity $(100 \mathrm{~L} / \mathrm{s})$, broke down. This contributed to a very low RIS of 0.68 . The water shortage in all the irrigation schemes is due to frequent power outages.

The average RIS values obtained are comparable to the average RIS value of 2.31 recorded in the large public rice irrigation schemes in the Senegal Valley in Mauritania [18]. An average RWS of 0.77 was obtained in Karacabey surface irrigation system, Turkey [29]. This irrigation scheme was reported to have a water shortage. Elsewhere in Turkey, [30] obtained RWS values ranging between 0.37 and 1.97. In Malaysia, RWS varied between 0.4 and 4.3, while RIS ranged between 0.5 and 5.7. The high values in Malaysia are attributed to extensive rice farming using open channels. An average RIS value of 1.38 was obtained for sprinkler irrigation systems and 1.03 for drip irrigation systems in Spain [17]. Sprinkler and drip irrigation systems have a high irrigation efficiency compared to the surface irrigation method. That is why the RIS values are lower compared to the values obtained in the Ahero, Bunyala and West Kano irrigation schemes.

The quantity of water supplied per unit area varies with the availability of water, climate, soil type, cropping pattern, system conditions and system management [31]. The annual water delivery per unit command area (WDCA) varied between $2269 \mathrm{~m}^{3} /$ ha (West Kano in 2014/2015) to 11,089 $\mathrm{m}^{3} / \mathrm{ha}$ (Bunyala in 2016/2017). The WDCA was $4389 \mathrm{~m}^{3} / \mathrm{ha}-7586 \mathrm{~m}^{3} /$ ha in Ahero, $2269 \mathrm{~m}^{3} / \mathrm{ha}-8583 \mathrm{~m}^{3} / \mathrm{ha}$ in West Kano and $6050 \mathrm{~m}^{3} / \mathrm{ha}-11,089 \mathrm{~m}^{3} / \mathrm{ha}$ in the Bunyala irrigation scheme. WDCA was highest in Bunyala, and least in the Ahero irrigation scheme. The annual water delivery per unit irrigated area (WDIA) varied from $5294 \mathrm{~m}^{3} /$ ha to $7785 \mathrm{~m}^{3} /$ ha in Ahero; $11,238 \mathrm{~m}^{3} /$ ha to $12,310 \mathrm{~m}^{3} /$ ha in West Kano and $6285 \mathrm{~m}^{3} /$ ha to $12,130 \mathrm{~m}^{3} /$ ha in the Bunyala irrigation scheme. This is equivalent to supplied depth of water of $529.4 \mathrm{~mm}-778.5 \mathrm{~mm}$ in Ahero, $1123.8 \mathrm{~mm}-1231 \mathrm{~mm}$ in West Kano, and $628.5 \mathrm{~mm}$ to $12,130 \mathrm{~mm}$ in the Bunyala irrigation scheme. According to the FAO, the average crop water needed for paddy rice should be $450 \mathrm{~mm}-700 \mathrm{~mm}$ [32]. Considering low irrigation efficiencies associated with surface irrigation schemes—usually 30-40\% [32] - the WDIA is adequate in the West Kano and Bunyala irrigation schemes. The Ahero irrigation scheme, on the other hand, supplies inadequate water, which is not enough to meet crop water needs. WDIA values are relatively lower compared to the 22,029.43 $\mathrm{m}^{3} / \mathrm{ha}, 16,026.37 \mathrm{~m}^{3} / \mathrm{ha}, 11,289.10 \mathrm{~m}^{3} / \mathrm{ha}$, and $9795.96 \mathrm{~m}^{3}$ / ha obtained in MARIIS, Divisoria, Lucban and Garab SWIPs, respectively, in the Cagayan river basin, Philippines [23]. In southern Italy, high WDIA values ranging between $6500-14,900 \mathrm{~m}^{3} /$ ha were reported by the Water Users' Association (WUA's) of Calabria [33]. WDIA values of $5578 \mathrm{~m}^{3} /$ ha were obtained in sprinkler irrigation systems and $1084 \mathrm{~m}^{3} /$ ha in drip irrigation systems in Castilla-La Mancha, Spain [17]. These values are much lower than the values obtained in this study. Drip and sprinkler irrigation systems have high water application efficiencies of $75 \%$ and $90 \%$, respectively [34]. Surface irrigation systems, on the other hand, have a low irrigation efficiency of $60 \%$. Therefore, more water is supplied in surface irrigation systems compared to sprinkler and drip irrigation systems. In the Susurluk river basin in Turkey, WDCA values varying from $1465 \mathrm{~m}^{3} /$ ha to $13,086 \mathrm{~m}^{3} /$ ha and WDCA values ranging from $2169 \mathrm{~m}^{3} /$ ha 
to $22,098 \mathrm{~m}^{3} /$ ha were obtained [30]. A high amount of water is supplied to irrigation schemes in the Sursurluk basin because rainfall is limited during the irrigation period.

\subsection{Financial Performance}

The financial performance indicators measure the efficiency with which irrigation systems use resources to provide service to farmers [23]. The results are shown in Table 7.

Table 7. Financial performance indicators.

\begin{tabular}{|c|c|c|c|c|c|}
\hline & & $\begin{array}{l}\text { Gross Revenue } \\
\text { Collected (US\$) }\end{array}$ & $\begin{array}{l}\text { Gross Revenue } \\
\text { Invoiced (US\$) }\end{array}$ & $\begin{array}{c}\text { Revenue } \\
\text { Collection } \\
\text { Performance (\%) }\end{array}$ & $\begin{array}{l}\text { Average Revenue per Unit } \\
\text { Irrigation Water Supply } \\
\text { (US Dollar Cents } / \mathrm{m}^{3} \text { ) }\end{array}$ \\
\hline \multirow{6}{*}{ WKIS } & $2012 / 2013$ & $24,979.50$ & $55,510.00$ & 45 & 0.36 \\
\hline & $2013 / 2014$ & 8910.72 & $18,564.00$ & 48 & 0.35 \\
\hline & $2014 / 2015$ & 8966.41 & $17,581.20$ & 51 & 0.40 \\
\hline & $2015 / 2016$ & $31,547.88$ & $58,422.00$ & 54 & 0.44 \\
\hline & $2016 / 2017$ & $35,375.34$ & $62,062.00$ & 57 & 0.42 \\
\hline & Average & $21,955.97$ & $42,427.84$ & 51 & 0.39 \\
\hline \multirow{6}{*}{ AIS } & $2012 / 2013$ & $67,208.00$ & $53,766.40$ & 80 & 0.79 \\
\hline & $2013 / 2014$ & $64,790.00$ & $55,071.50$ & 85 & 1.12 \\
\hline & $2014 / 2015$ & $59,985.00$ & $49,187.70$ & 82 & 1.01 \\
\hline & $2015 / 2016$ & $63,147.00$ & $54,306.42$ & 86 & 1.24 \\
\hline & $2016 / 2017$ & $55,180.00$ & $49,662.00$ & 90 & 1.26 \\
\hline & Average & $62,062.00$ & $52,398.80$ & 85 & 1.08 \\
\hline \multirow{6}{*}{ BIS } & $2012 / 2013$ & $69,280.00$ & $63,737.60$ & 92 & 1.45 \\
\hline & $2013 / 2014$ & $69,280.00$ & $65,123.20$ & 94 & 1.05 \\
\hline & $2014 / 2015$ & $69,280.00$ & $64,430.40$ & 93 & 1.19 \\
\hline & $2015 / 2016$ & $61,770.00$ & $58,681.50$ & 95 & 1.09 \\
\hline & $2016 / 2017$ & $65,820.00$ & $63,811.20$ & 97 & 0.79 \\
\hline & Average & $67,086.00$ & $63,156.78$ & 94 & 1.11 \\
\hline
\end{tabular}

Water fee collection performance (WFC) values obtained are $80-90 \%$ in the Ahero irrigation scheme, $45-57 \%$ in the West Kano irrigation scheme, and $92-97 \%$ in the Bunyala irrigation scheme. According to [18], water fee collection values below $70 \%$ are considered unsatisfactory. Bunyala has the highest average fee collection performance, at $94 \%$, while West Kano has the lowest average value, at $51 \%$. The ideal desirable value should be close to $100 \%$ [10]. De Alwis and Wijesekara [35] obtained an ideal WFC of 100\% in the Beypazarı Başören irrigation system, Turkey. Similarly, a WFC of 103\% was recorded in the Karacabey irrigation scheme in Turkey. Values of WFC equal to or above $100 \%$ show that water users are willing to pay for the cost of irrigation. WFC values above $100 \%$ are possible to obtain due to payment of accumulated arrears. Low WFC values point out an unwillingness of farmers to pay water fees, poor organisation of the Irrigation Water Users Association (IWUA), poor collection programs, and financial problems within the schemes. Bunyala is able to sustain a value above $90 \%$ because of the well-organised farmer groups that are mandated with the mobilisation of the water fee. Also, in Bunyala, the policy of water fee payment prior to ploughing is strictly followed.

The average revenue per unit cubic meter varied from 0.79 to 1.26 US cents in the Ahero irrigation scheme, 0.35 to 0.44 US cents in the West Kano irrigation scheme, and 0.79 to 1.45 US cents in the Bunyala irrigation scheme. These values are below the economic value of irrigation water of 7.54 US cents per cubic meter obtained by [27] in the Ahero irrigation scheme. Pricing of water is an economic aid to improving water allocation and sustainable water utilisation [30]. The water fee charged is US\$31, US $\$ 36.40$ and US $\$ 40$ per acre in the Ahero, West Kano and Bunyala irrigation schemes, respectively. The pricing is based on area cropped per farming season and not the quantity of water consumed. There is no limit to the quantity of water that a farmer can use. This explains why the value of water per cubic meter is below 1 US\$. This is a weakness and is unsuitable in terms of efficiency of water 
use and water conservation. Bunyala is the best performing irrigation scheme under the financial performance category.

\subsection{Agricultural Productivity}

Agricultural productivity gives the relationship between inputs and output. It gives an indication of efficiency of crop production in terms of land used, amount of water used and the income generated [36]. The indicators are presented in Table 8.

Table 8. Agricultural productivity indicators.

\begin{tabular}{|c|c|c|c|c|c|c|c|c|}
\hline $\begin{array}{l}\text { Irrigation } \\
\text { Scheme }\end{array}$ & Year & $\begin{array}{c}\text { AGP } \\
\text { (Tones) }\end{array}$ & $\begin{array}{l}\text { GVP } \\
\text { (US\$) }\end{array}$ & $\begin{array}{c}\text { OIA } \\
\text { (US\$/ha) }\end{array}$ & $\begin{array}{c}\text { OCA } \\
\text { (US\$/ha) }\end{array}$ & $\begin{array}{c}\text { OIS } \\
\left(\mathrm{US} \$ / \mathrm{m}^{3}\right)\end{array}$ & $\begin{array}{c}\text { OWS } \\
\left(\mathrm{US} \$ \mathrm{~m}^{3}\right)\end{array}$ & $\begin{array}{l}\text { OCWD } \\
\left(\mathrm{US} \$ / \mathrm{m}^{3}\right)\end{array}$ \\
\hline \multirow{5}{*}{ West Kano } & $2012 / 2013$ & 2679 & 857,120 & 950 & 1389 & 0.12 & 0.09 & 0.21 \\
\hline & $2013 / 2014$ & 1201 & 420,308 & 466 & 2036 & 0.17 & 0.13 & 0.26 \\
\hline & $2014 / 2015$ & 1136 & 374,959 & 416 & 1918 & 0.17 & 0.12 & 0.27 \\
\hline & $2015 / 2016$ & 3633 & $1,307,837$ & 1450 & 2014 & 0.18 & 0.14 & 0.26 \\
\hline & $2016 / 2017$ & 4083 & $1,551,707$ & 1720 & 2249 & 0.18 & 0.15 & 0.28 \\
\hline Average & & 2546 & 902,386 & 1000 & 1921 & 0.17 & 0.13 & 0.26 \\
\hline \multirow{5}{*}{ Ahero } & $2012 / 2013$ & 4179 & $1,677,200$ & 1864 & 1912 & 0.25 & 0.14 & 0.28 \\
\hline & $2013 / 2014$ & 4182 & $1,479,800$ & 1644 & 1749 & 0.30 & 0.20 & 0.22 \\
\hline & $2014 / 2015$ & 4551 & $1,683,870$ & 1871 & 2151 & 0.35 & 0.20 & 0.29 \\
\hline & $2015 / 2016$ & 4465 & $1,741,370$ & 1935 & 2113 & 0.40 & 0.21 & 0.27 \\
\hline & $2016 / 2017$ & 4058 & $1,663,780$ & 1849 & 2311 & 0.42 & 0.22 & 0.28 \\
\hline Average & & 4287 & $1,649,204$ & 1832 & 2047 & 0.34 & 0.20 & 0.27 \\
\hline \multirow{5}{*}{ Bunyala } & $2012 / 2013$ & 3803 & $1,248,221$ & 1714 & 1781 & 0.28 & 0.15 & 0.29 \\
\hline & $2013 / 2014$ & 2146 & 714,678 & 981 & 1020 & 0.11 & 0.07 & 0.16 \\
\hline & $2014 / 2015$ & 3380 & $1,132,300$ & 1554 & 1615 & 0.21 & 0.13 & 0.26 \\
\hline & $2015 / 2016$ & 3850 & $1,321,617$ & 1814 & 2115 & 0.25 & 0.15 & 0.34 \\
\hline & $2016 / 2017$ & 3633 & $1,214,772$ & 1668 & 1824 & 0.15 & 0.11 & 0.28 \\
\hline Average & & 3362 & $1,126,318$ & 1546 & 1671 & 0.20 & 0.12 & 0.27 \\
\hline
\end{tabular}

The output per unit irrigation supply (OIS) ranges between $0.11 \mathrm{US} \$ / \mathrm{m}^{3}$ and $0.42 \mathrm{US} \$ / \mathrm{m}^{3}$ in all the schemes. The average, OIS is $0.34 \mathrm{US} \$ / \mathrm{m}^{3}$ in Ahero, $0.17 \mathrm{US} \$ / \mathrm{m}^{3}$ in West Kano, and $0.20 \mathrm{US} \$ / \mathrm{m}^{3}$ in the Bunyala irrigation scheme. Ahero irrigation scheme utilises water more efficiently compared to the others. The output per unit water supply (OWS) puts into consideration the contribution of effective rainfall. The values vary between 0.07 and $0.22 \mathrm{US} \$ / \mathrm{m}^{3}$. The highest OCWD value $\left(0.34 \mathrm{US} \$ / \mathrm{m}^{3}\right)$ was obtained in the Bunyala irrigation scheme in $2015 / 2016$, while the lowest value $\left(0.16 \mathrm{US} \$ / \mathrm{m}^{3}\right)$ was recorded in Bunyala in 2013/2014. The Ahero and Bunyala irrigation schemes have the highest average OCWD of $0.27 \mathrm{US} \$ / \mathrm{m}^{3}$, while West Kano irrigation scheme has the lowest average value of $0.26 \mathrm{US} \$ / \mathrm{m}^{3}$. The Ahero irrigation scheme is leading in terms of water productivity while West Kano is the poorest. According to [15], if OCWD is greater than OIS, some of the irrigation water supplied is unproductive. In both West Kano and Bunyala, OIS is greater than OCWD. This shows inefficient use of water. The Ahero irrigation scheme is the most efficient water user, with all OIS values less than OCWD except in 2012/2013. The difference in water productivity is brought about by differences in yield and crop market price. In similar studies in Malaysia, [37] reported OWS values ranging between $0.01 \mathrm{US} \$ / \mathrm{m}^{3}$ and $0.2 \mathrm{US} \$ / \mathrm{m}^{3}$ and OCWD values varying from $0.01 \mathrm{US} \$ / \mathrm{m}^{3}$ to $0.4 \mathrm{US} \$ / \mathrm{m}^{3}$ for paddy rice. Compared to this, the Ahero, West Kano and Bunyala irrigation schemes registered higher rice water productivity. The difference is attributed to the yield and market price. Mchele [38] obtained OIS values of $0.95 \mathrm{US} \$ / \mathrm{m}^{3}$ in Shina-Hamusit and $0.62 \mathrm{US} \$ / \mathrm{m}^{3}$ in the Selamko irrigation scheme, and OCWD values of $1.46 \mathrm{US} \$ / \mathrm{m}^{3}$ in Shina-Hamusit and $1.15 \mathrm{US} \$ / \mathrm{m}^{3}$ in the Selamko irrigation scheme, Ethiopia. These irrigation schemes do not grow rice. This shows that rice is a competitive crop in terms of returns per water used. In Turkey, OCWD values varying between $0.191 \mathrm{US} \$ / \mathrm{m}^{3}$ and $1.262 \mathrm{US} \$ / \mathrm{m}^{3}$ 
were obtained [30]. The highest values of rice water productivity of $1.77 \mathrm{~kg} / \mathrm{m}^{3}, 1.75 \mathrm{~kg} / \mathrm{m}^{3}$ and $1.51 \mathrm{~kg} / \mathrm{m}^{3}$ have been reported in the USA, Sri Lanka and Spain, respectively [26].

Land productivity indicators give a reflection of crop intensity [39]. The output per unit command area (OCA) varies between 1020 US\$/ha (Bunyala in 2013/2014) and 2311 US\$/ha (Ahero in 2016/2017). The average OCA computed was 2047 US\$/ha in Ahero; 1921 US\$/ha in West Kano and 1671 US\$/ha in the Bunyala irrigation scheme. A high value is an indication of intensive irrigation. The sudden fall in output per command area in West Kano between 2012 and 2014 can be attributed to the collapse of the Revolving Fund Committee. The committee was mandated with the responsibility for production and marketing in the West Kano irrigation scheme. Consequently, there was a decline in production activities during that period associated with governance issues. From 2015 each block in the scheme established a production management structure which induced competition amongst the blocks in terms of production activities. An increase in production was therefore realised in 2015/2016. The Bunyala irrigation scheme experienced hail in 2013 which shattered mature rice crops in one of the phases (Muluwa phase 1). This contributed to a low harvest, as depicted by the sudden decline in the output per unit area in the scheme. The output per unit irrigated area (OIA) for all the schemes varied from 981 US $\$$ / ha to 1841 US $\$ /$ ha. The OIA values computed are comparable to the OIA values of 1300 US\$/ha and 1310 US\$/ha obtained during the rainy season and dry season in rice farming in Thailand [40]. OIA values ranging from $100 \mathrm{US} \$ /$ ha to 800 US $\$ /$ ha were reported in Malaysia [37].

\subsection{Estimation of Overall Scheme Performance}

Correlation analysis of the 11 selected indicators is presented in Table 9. RWS and RIS are strongly positively correlated $(r=0.950)$. This means that the indicators measure similar elements. To avoid double counting, only one of them can be used in the computation of the composite indicator/performance score. RIS focuses on irrigation water supply alone and is therefore used for computation of the performance score.

Table 9. Pearson correlation matrix $(n)$.

\begin{tabular}{cccccccccccc}
\hline Variables & RWS & RIS & WDIA & WDCA & WFC & RIWS & OIA & OCA & OIS & OCWD & OWS \\
\hline RWS & 1 & 0.950 & 0.711 & 0.458 & -0.168 & -0.425 & -0.185 & -0.305 & -0.801 & 0.278 & -0.855 \\
RIS & 0.950 & 1 & 0.648 & 0.455 & -0.259 & -0.457 & -0.273 & -0.292 & -0.778 & 0.189 & -0.845 \\
ISIA & 0.711 & 0.648 & 1 & 0.283 & -0.645 & -0.873 & 0.092 & -0.570 & -0.870 & 0.060 & -0.701 \\
ISCA & 0.458 & 0.455 & 0.283 & 1 & 0.284 & -0.029 & -0.312 & 0.475 & -0.432 & -0.047 & -0.471 \\
WFC & -0.168 & -0.259 & -0.645 & 0.284 & 1 & 0.889 & -0.180 & 0.696 & 0.469 & 0.125 & 0.278 \\
ARIS & -0.425 & -0.457 & -0.873 & -0.029 & 0.889 & 1 & -0.125 & 0.662 & 0.723 & 0.109 & 0.514 \\
OIA & -0.185 & -0.273 & 0.092 & -0.312 & -0.180 & -0.125 & 1 & 0.156 & 0.375 & 0.741 & 0.553 \\
OCA & -0.305 & -0.292 & -0.570 & 0.475 & 0.696 & 0.662 & 0.156 & 1 & 0.566 & 0.301 & 0.480 \\
OIS & -0.801 & -0.778 & -0.870 & -0.432 & 0.469 & 0.723 & 0.375 & 0.566 & 1 & 0.217 & 0.936 \\
OWC & 0.278 & 0.189 & 0.060 & -0.047 & 0.125 & 0.109 & 0.741 & 0.301 & 0.217 & 1 \\
OWS & -0.855 & -0.845 & -0.701 & -0.471 & 0.278 & 0.514 & 0.553 & 0.480 & 0.936 & 0.245 \\
\hline
\end{tabular}

RWS-relative water supply; RIS-relative irrigation supply; WDIA-Water delivery per unit irrigated area; WDCA—-water delivery per unit command area; WFC—-water fee collection; RIWS - annual revenue per unit irrigation water supply; OIA—output per unit irrigated area; OCA—output per unit command area; OIS—output per unit irrigation supply; OCWD—output per unit crop water demand; OWS—output per unit water supply.

\section{Principal Component Analysis}

The extracted principal factors, Kaiser-Meyer-Olkin (KMO) measure of sampling adequacy and Bartlett's sphericity test (BTS) results are presented in Table 10.

According to [41], if the KMO value is greater than 0.5 and the BTS less than 0.05 , the data is suitable for PCA. In this study, the KMO co-efficient of 0.510 is adequate and the Bartlett's test is significant at $99 \%(p<0.0001)$. The principal components extracted with their factor loadings are presented in Table 11. The indicator weights are also presented in this Table 11. 
Table 10. Kaiser-Meyer-Olkin (KMO) and Bartlett's test.

\begin{tabular}{ccc}
\hline \multicolumn{3}{c}{ KMO and Bartlett's Test } \\
\hline \multicolumn{2}{c}{ Kaiser-Meyer-Olkin Measure of Sampling Adequacy. } & 0.510 \\
\hline & Approx. Chi-Square & 211.443 \\
Bartlett's Test of Sphericity & df & 45 \\
& Sig. & 0.000 \\
\hline
\end{tabular}

Table 11. The extracted principal components.

\begin{tabular}{|c|c|c|c|c|}
\hline \multicolumn{4}{|c|}{ Rotated Component Matrix (Factor Loading) } & Indicator Weights \\
\hline & 1 & 2 & 3 & \\
\hline$\%$ of variance & 34.959 & 34.918 & 19.930 & \\
\hline Relative irrigation supply (RIS) & -0.222 & -0.876 & 0.044 & 0.091 \\
\hline Water delivery per unit irrigated area (WDIA) & -0.673 & -0.669 & 0.169 & 0.104 \\
\hline Average revenue per unit irrigation water supply (RIWS) & 0.862 & 0.387 & -0.086 & 0.100 \\
\hline Output per unit irrigated area (OIA) & -0.161 & 0.317 & 0.912 & 0.107 \\
\hline Output per unit command area (OCA) & 0.891 & 0.040 & 0.289 & 0.098 \\
\hline Output per unit irrigation supply (OIS) & 0.505 & 0.815 & 0.229 & 0.108 \\
\hline Output per crop water demand (OCWD) & 0.149 & -0.081 & 0.925 & 0.098 \\
\hline output per unit water supply (OWS) & 0.318 & 0.848 & 0.353 & 0.105 \\
\hline
\end{tabular}

Extraction Method: Principal Component Analysis. Rotation Method: Varimax with Kaiser Normalisation.

The first principal component (PC1) determines 34.9595\% of the total variance in performance. The first principal component is mainly linked to indicators with absolute factor loading greater than 0.673 (WDIA, WFC, RIWS, OCA). The second principal component (PC2) accounts for $34.918 \%$ of the variance in performance. It is influenced by RIS, WDCA, OIS and OWS indicators (absolute loadings $>0.794$ ). The third principal component (PC3) factor loading accounts for $19.93 \%$ and is linked with OIA and OCWD indicators.

The results of weighted indicators are presented in Table 12. The performance score for each scheme in each year was obtained by summing up the weighted indicator values.

Table 12. Weighted performance score for each category.

\begin{tabular}{cccccccccccccc}
\hline Year & IS & RIS & WSIA & WSCA & WFC & ARIWS & OIA & OCA & OIS & OCWD & OWS & PS \\
\hline \multirow{2}{*}{$2012 / 2013$} & AIS & 0.10 & 0.07 & 0.06 & 0.08 & 0.01 & 0.06 & 0.05 & 0.03 & 0.03 & 0.02 & 0.52 \\
& WKIS & 0.14 & 0.10 & 0.06 & 0.04 & 0.00 & 0.05 & 0.03 & 0.02 & 0.03 & 0.02 & 0.51 \\
& BIS & 0.09 & 0.06 & 0.05 & 0.09 & 0.02 & 0.07 & 0.06 & 0.05 & 0.04 & 0.02 & 0.54 \\
\hline \multirow{2}{*}{$2013 / 2014$} & AIS & 0.04 & 0.05 & 0.05 & 0.08 & 0.01 & 0.06 & 0.05 & 0.05 & 0.03 & 0.03 & 0.45 \\
& WKIS & 0.07 & 0.11 & 0.02 & 0.05 & 0.00 & 0.07 & 0.01 & 0.03 & 0.04 & 0.02 & 0.43 \\
& BIS & 0.10 & 0.08 & 0.07 & 0.09 & 0.01 & 0.04 & 0.03 & 0.02 & 0.02 & 0.01 & 0.48 \\
\hline \multirow{2}{*}{$2014 / 2015$} & AIS & 0.06 & 0.06 & 0.04 & 0.08 & 0.01 & 0.07 & 0.06 & 0.05 & 0.04 & 0.03 & 0.49 \\
& WKIS & 0.11 & 0.10 & 0.02 & 0.05 & 0.01 & 0.07 & 0.01 & 0.03 & 0.04 & 0.02 & 0.46 \\
& BIS & 0.10 & 0.07 & 0.06 & 0.09 & 0.02 & 0.06 & 0.05 & 0.03 & 0.04 & 0.02 & 0.54 \\
\hline & AIS & 0.04 & 0.05 & 0.04 & 0.08 & 0.02 & 0.07 & 0.06 & 0.06 & 0.03 & 0.03 & 0.47 \\
$2015 / 2016$ & WKIS & 0.09 & 0.10 & 0.07 & 0.05 & 0.01 & 0.07 & 0.04 & 0.03 & 0.04 & 0.02 & 0.51 \\
& BIS & 0.11 & 0.08 & 0.06 & 0.09 & 0.01 & 0.07 & 0.06 & 0.04 & 0.05 & 0.02 & 0.60 \\
\hline & AIS & 0.04 & 0.05 & 0.04 & 0.09 & 0.02 & 0.07 & 0.05 & 0.06 & 0.03 & 0.03 & 0.47 \\
& WKIS & 0.08 & 0.11 & 0.08 & 0.05 & 0.01 & 0.07 & 0.05 & 0.03 & 0.04 & 0.02 & 0.54 \\
& BIS & 0.11 & 0.11 & 0.09 & 0.09 & 0.01 & 0.07 & 0.06 & 0.02 & 0.04 & 0.02 & 0.62 \\
\hline
\end{tabular}

IS-Irrigation scheme; AIS—Ahero irrigation scheme; WKIS—WKano irrigation scheme; BIS—Bunyala irrigation scheme; RIS—relative irrigation supply; WSIA—irrigation supply per unit irrigated area; WSCA—irrigation supply per unit command area; WFC — water fee collection; ARIWS - annual revenue per unit irrigation supply; OIA-output per unit irrigated area; OCA—output per unit command area; OIS—output per unit irrigation supply; OCWD—output per unit water consumed; OWS—output per unit water supply. 
Comparison of the trend in irrigation scheme performance of each scheme is presented in Figure 2.

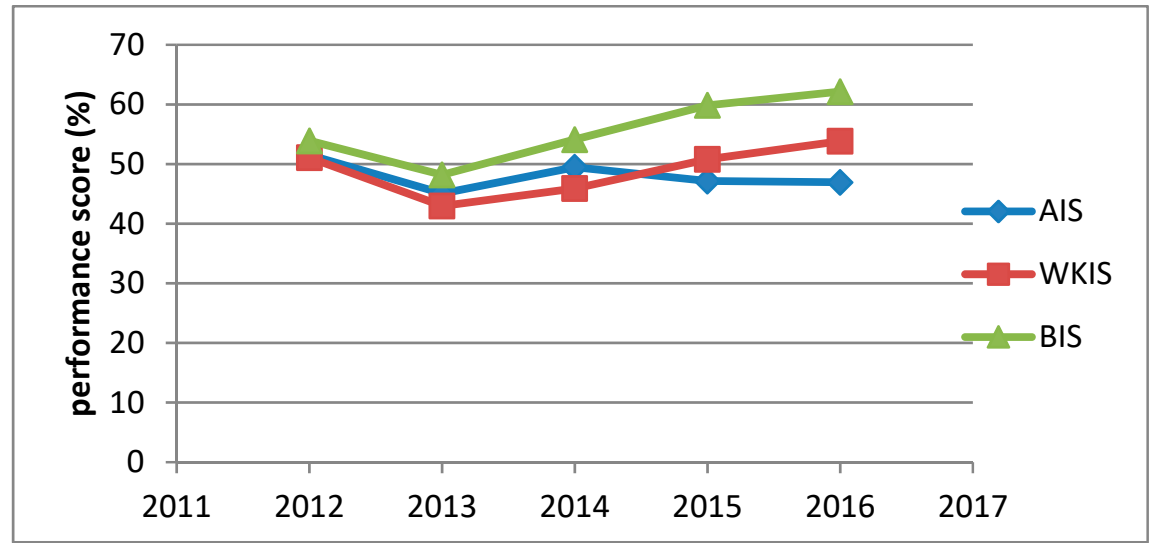

Figure 2. Comparison of performance score.

The overall performance score obtained was $45-52 \%$ in Ahero, $43-54 \%$ in West Kano and $48-62 \%$ in the Bunyala irrigation scheme. The average performance was $48 \%$, $49 \%$ and $56 \%$ in the Ahero, West Kano and Bunyala irrigation schemes, respectively. The performance in all of the schemes was moderate. The performance in the West Kano and Bunyala irrigation schemes increased with time. The performance in the Ahero irrigation scheme was seen to be decreasing with time. The West Kano irrigation scheme experienced a fall in performance in 2014 due to the collapse of the Revolving Fund Committee which was mandated with the responsibility of production and marketing. The establishment of the production management structure, which created competition among the blocks in terms of production, increased performance from 2015. The sudden decline in performance in Bunyala in 2013 was due to hail stones that shattered mature rice crops in one of the phases (Muluwa phase 1). The reduction in the amount of water available due to drought led to a decrease in performance in the Ahero irrigation scheme in 2013. In 2013, there was strong sensitisation in the System of Rice Intensification (SRI) technology in Ahero. SRI involves changes in plants, water soil and nutrients management aimed at increasing productivity of rice under irrigation. Most farmers in the Ahero irrigation scheme adopted SRI, which led to an increase in performance from $45 \%$ in 2013 to $49 \%$ in 2014. A high performance of 83\% [12] was obtained in the Samrat Ashok Sagar major irrigation project in India using a balanced score card method based on the Delphi technique. Agricultural productivity in India is highly enhanced by the government through artificial fixing of the minimum price of crops. The prices are therefore reasonably high, leading to the high economic value of crops. This is not the case in Kenya, where the price of rice produce is governed by market forces. In times of surplus, rice fetches low prices, reducing its economic value. This contributes greatly to low agricultural productivity performance, leading to low overall performance of irrigation schemes. Zema and Nicotra [42] used PCA to identify areas of weakness in seven Water Users' Association (WUA's) in Calabra, Southern Italy. The Ionio Catanzarese (ICZ) WUA was ranked as the best performing with a quality index of 4470, while the Basso Ionio Reggino (BIRC) was found to be the least performing with a quality index of -1410 . BIRC was found to have a weakness in both system operation performance and financial management. Lowering water prices was found to be the solution to improving performance of BRIC WUA's in Calabra, Southern Italy [42].

\section{Conclusions}

The combination of benchmarking and Principal Component Analysis forms a powerful tool for evaluating the efficiency of irrigation schemes. The quantitative evaluation of performance of three rice irrigation schemes in western Kenya using a set of benchmarking indicators revealed the areas that needed improvement. Analysis of water supply indicators shows that, the water supplied by the 
irrigation schemes is sufficient to meet crop water demands. The irrigation schemes have low water use efficiency. In terms of financial performance, the irrigation schemes are not financially self-sufficient. The water fee charged was not sufficient to pay for the cost of irrigation. Land and water productivity in western Kenyan rice irrigation schemes was found to be generally good. Computation of a single performance score using performance indicators and principal component analysis enabled ranking of the irrigation schemes. The Bunyala irrigation scheme was found to be the best performing scheme, whereas the Ahero irrigation scheme was the least performing in the region. The overall performance of public rice irrigation schemes in western Kenya is average. Operation and management measures should be put in place to improve performance. The schemes need to adopt a systematic routine data collection and management to aid in the monitoring and evaluation of performance. Stakeholders and scheme managers can use this information to reformulate policies and strategies to enhance performance of public rice irrigation schemes in Kenya.

Author Contributions: F.M.M. designed the methodology, analysed data, interpreted the results and prepared the manuscript. P.G.H. conceived the research idea. J.M.R. assisted in obtaining the datasets. P.G.H. and J.M.R. guided in analysis and correction of the initial draft.

Funding: This research was funded by the African Union Commission (AUC) and Japan International Cooperation Agency (JICA).

Acknowledgments: The authors are grateful to National Irrigation Board (NIB) for granting access to western Kenyan irrigation schemes. We are also grateful to the Kenya Meteorological Department (KMD) and the management of the Ahero, Bunyala and West Kano irrigation schemes for providing historical data sets for this study.

Conflicts of Interest: The authors have no conflict of interest.

\section{References}

1. Government of Kenya. National Water Master Plan 2030 in the Republic of Kenya Final Report Volume -v Sectoral Report (2/3); Government of Kenya: Nairobi, Kenya, 2013.

2. Ngenoh, E.; Kirui, L.K.; Mutai, B.K.; Maina, M.C.; Koech, W.; Victoria, L. Economic Determinants of the Performance of Public Irrigation Schemes in Kenya. J. Dev. Agric. Econ. 2015, 7, 344-352. [CrossRef]

3. Gitonga, K. Grain and Feed Annual 2017 Kenya Corn, Wheat and Rice Report; USDA Foreign Agricultural Service: Washington, DC, USA, 2017.

4. Ministry of Water and Irrigation. Irrigation Sub-Sector MTP111 Zero Draft (2); Ministry of Water and Irrigation: Nairobi, Kenya, 2017.

5. Evans, A.A.; Florence, N.O.; Eucabeth, B.O.M. Production and Marketing of Rice in Kenya: Challenges and Opportunities. J. Dev. Agric. Econ. 2018, 10, 64-70. [CrossRef]

6. Kenya National Bureau of Statistics (KNBS). Economic Survey of Kenya; KNBS: Nairobi, Kenya, 2016.

7. Kenya National Bureau of Statistics (KNBS). Kenya Population Census Report; KNBS: Nairobi, Kenya, 2010.

8. Krhoda, G.O. Kenya National Water Development Report; UN-Water: Geneva, Switzerland, 2006; pp. 1-244.

9. Ngigi, S.N. Review of Irrigation Development in Kenya. In The Changing Face of Irrigation in Kenya: Opportunities for Anticipating Change in Eastern and Southern Africa; Blank, H.G., Mutero, C.M., Murray-Rust, H., Eds.; International Water Management Institute (IWMI): Colombo, Sri Lanka, 2002; Volume XIV, pp. 35-54.

10. Malano, H.; Burton, M.; Makin, I. Guidelines for Benchmarking Performance in the Irrigation and Drainage Sector, 1st ed.; International Programme for Technology and Research in Irrigation and Drainage (IPTRID) Knowledge Synthesis Report No. 5; FAO: Rome, Italy, 2001; Volume 53.

11. Malano, H.; Hungspreug, S.; Plantey, J.; Bos, M.G.; Vlotman, W.F.; Molden, D.; Burton, M. Benchmarking of Irrigation and Drainage Projects; International Commission on Irrigation and Drainage (ICID): New Delhi, India, 2004.

12. Phadnis, S.S.; Kulshrestha, M. Evaluation for Measuring Irrigation Service Performance Using a Scorecard Framework. Irrig. Drain. 2013, 62, 181-192. [CrossRef]

13. Renault, D.; Facon, T.; Wahaj, R. Modernizing Irrigation Management: The MASSCOTE Approach-Mapping System and Services for Canal Operation Techniques; Food and Agriculture Organization: Rome, Italy, 2007; Volume 63. 
14. Burt, C.M.; Styles, S.W. Rapid Appraisal Process (RAP) and Benchmarking. Bioresour. Agric. Eng. 2001, 32-80.

15. Molden, D.; Sakthivadivel, R.; Perry, C.J.; De Fraiture, C.; Kloezen, W.H. Indicators for Comparing Performance of Irrigated Agricultural Systems; IWMI: Colombo, Sri Lanka, 1998; ISBN 9290903562.

16. Rodríguez Díaz, J.A.; Camacho-Poyato, E.; López-Luque, R.; Perez-Urrestarazu, L. Benchmarking and Multivariate Data Analysis Techniques for Improving the Efficiency of Irrigation Districts: An Application in Spain. Agric. Syst. 2008, 96, 250-259. [CrossRef]

17. Córcoles, J.I.; de Juan, J.A.; Ortega, J.F.; Tarjuelo, J.M.; Moreno, M.A. Evaluation of Irrigation Systems by Using Benchmarking Techniques. J. Irrig. Drain. Eng. 2012, 138, 225-234. [CrossRef]

18. Borgia, C.; García-Bolaños, M.; Li, T.; Gómez-Macpherson, H.; Comas, J.; Connor, D.; Mateos, L. Benchmarking for Performance Assessment of Small and Large Irrigation Schemes along the Senegal Valley in Mauritania. Agric. Water Manag. 2013, 121, 19-26. [CrossRef]

19. Jamilah, M.; Zakaria, A.; Md. Shakaff, A.Y.; Idayu, N.; Hamid, H.; Subari, N.; Mohamad, J. Principal Component Analysis-A Realization of Classification Success in Multi Sensor Data Fusion. In Principal Component Analysis_Engineering Applications; InTech: Philadelphia, PA, USA, 2012; pp. 1-25. [CrossRef]

20. Paul, L.C.; Suman, A.A.; Sultan, N. Methodological Analysis of Principal Component Analysis (PCA) Method. Int. J. Comput. Eng. Manag. 2013, 16, 32-38.

21. OECD. Handbook on Constructing Composite Indicators: Methodology and User Guide; OECD Publishing: Paris, France, 2008.

22. Kipkorir, E.C. Rice productivity, Water and Sanitation Baseline Survey Report Western Kenya Rice Irrigation Schemes. Available online: https://www.researchgate.net/publication/322686337_Rice_productivity_ Water_and_Sanitation_Baseline_Survey_Report_Western_Kenya_Rice_Irrigation_Schemes (accessed on 11 October 2018).

23. Balderama, O.F.; Bareng, J.L.R.; Alejo, L.A. Benchmarking for Performance Assessment of Irrigation Schemes: The Case of National Irrigation Systems and Small Water Impounding Projects in Cagayan River Basin. In Proceedings of the International Conference of Agricultural Engineering, Zurich, Switzerland, 6-10 July 2014.

24. Brouwer, C.; Heibloem, M. Irrigation Water Management: Irrigation Water Needs. Train. Man. 1986, 3, 225-240.

25. Bastiaanssen, W.; Perry, C. Agricultural Water Use and Water Productivity in the Large Scale Irrigation (LSI) Schemes of the Nile Basin; Nile Information System: Entebbe, Uganda, 2009.

26. Bastiaanssen, W.G.M.; Steduto, P. The Water Productivity Score (WPS) at Global and Regional Level: Methodology and First Results from Remote Sensing Measurements of Wheat, Rice and Maize. Sci. Total Environ. 2017, 575, 595-611. [CrossRef] [PubMed]

27. Omondi, S.O. Economic Valuatio of Irrigation Water in Ahero Irrigation Scheme; University of Nairobi: Nairobi, Kenya, 2014.

28. Bos, M.G.; Burton, M.A.; Molden, D.J. Irrigation and Drainage Performance Assessment Practical Guidelines; CABI Publishing: Wallingford, UK, 2005; ISBN 0851999670.

29. Kuscu, H.; Bölüktepe, F.E.; Demir, A.O. Evaluation Performance of Irrigation Water Management: A Case Study of Karacabey Irrigation Scheme in Turkey. Int. J. Agric. Sci. 2015, 5, 824-831.

30. Kuşçu, H. Benchmarking Performance Assessment of Irrigation Water Management in a River Basin: Case Study of the Susurluk River Basin, Turkey. Afr. J. Bus. Manag. 2012, 6, 2848-2859. [CrossRef]

31. Government of Maharashtra. Report on Benchmarking of Irrigation Projects in Maharashtra; Government of Maharashtra: Mumbai, India, 2005.

32. Brouwer, C.; Prins, K.; Heibloem, M. Irrigation Water Management: Irrigation Scheduling. Train. Man. 1989, 4,66 .

33. Zema, D.A.; Nicotra, A.; Zimbone, S.M. Diagnosis and Improvement of the Collective Irrigation and Drainage Services in Water Users' Associations of Calabria (Southern Italy). Irrig. Drain. 2018. [CrossRef]

34. Brouwer, C.; Prins, K.; Kay, M.; Heibloem, M. Irrigation Water Management: Irrigation Methods. Train. Man. 1998, 5, 140.

35. Cin, S.; Çakmak, B. Assessment of Irrigation Performance in Başören Irrigation Cooperative Area of Beypazar1, Ankara. J. Agric. Fac. Gaziosmanpasa Univ. 2017, 34, 10-19. [CrossRef] 
36. De Alwis, S.M.D.L.K.; Wijesekara, N.T.S. Comparison of Performance Assessment Indicators for Evaluation of Irrigation Scheme Performances in Sri Lanka. Engineer 2011, 44, 39-50. [CrossRef]

37. Ghazalli, M.A. Benchmarking of Irrigation Projects in Malaysia: Initial Implementation Stages and Preliminary Results. Irrig. Drain. 2004, 53, 195-212. [CrossRef]

38. Shenkut, A. Performance Assessment Irrigation Schemes According to Comparative Indicators: A Case Study of Shina-Hamusit and Selamko, Ethiopia. Int. J. Sci. Res. Publ. 2015, 5, 451-460.

39. Mchele, A.R. Summary for Policymakers. In Climate Change 2013-The Physical Science Basis; Intergovernmental Panel on Climate Change, Ed.; Cambridge University Press: Cambridge, UK, 2011; Volume 53, pp. 1-30.

40. Bumbudsanpharoke, W.; Prajamwong, S. Performance Assessment for Irrigation Water Management: Case Study of the Great Chao Phraya Irrigation Scheme. Irrig. Drain. 2015, 64, 205-214. [CrossRef]

41. Kalantari, K.H. Processing and Analysis of Economic Data in Social Research. Publ. Consult. Eng. Landsc. Des. Tehran 2008, 3, 110-122.

42. Zema, D.A.; Nicotra, A.; Tamburino, V. Performance Assessment of Collective Irrigation in Water Users' Associations of Calabria (Southern Italy). Irrig. Drain. 2015, 64, 314-325. [CrossRef]

(C) 2018 by the authors. Licensee MDPI, Basel, Switzerland. This article is an open access article distributed under the terms and conditions of the Creative Commons Attribution (CC BY) license (http:/ / creativecommons.org/licenses/by/4.0/). 